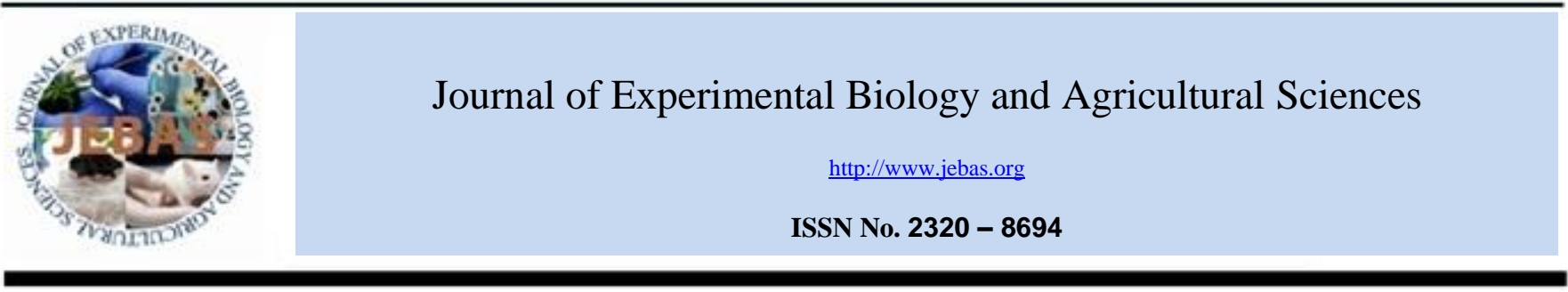

\title{
EVOLVING VIEWS ON ENTERIC VIRAL INFECTIONS OF EQUINES: AN APPRAISAL OF KEY PATHOGENS
}

\section{Shubhankar Sircar ${ }^{1}$, Sharad Saurabh ${ }^{1}$, Jobin J. Kattoor ${ }^{1}$, Pallavi Deol ${ }^{1}$, Kuldeep Dhama ${ }^{1}$, Sandip K Khurana $^{2}$ and Yashpal S. Malik ${ }^{1, *}$}

${ }^{1}$ ICAR-Indian Veterinary Research Institute, Izatnagar 243 122, Uttar Pradesh, India

${ }^{2}$ ICAR-National Research Centre on Equines, Hisar - 125 001, Haryana, India

Received - November 08, 2016; Revision - November 22, 2016; Accepted - December 01, 2016

Available Online - December 04, 2016

DOI: http://dx.doi.org/10.18006/2016.4(Spl-4-EHIDZ).S182.S195

KEYWORDS
Equines
Enteric
Virus
Epidemiology
Diagnosis
Control

\section{ABSTRACT}

Equines, the earliest known mammalian species, have been found highly susceptible to several enteric pathogens including viruses, fungi, parasites and bacteria. This review conserves with the key viral pathogens that affects foals and horses such as rotavirus, adenovirus, coronavirus, parvovirus, picobirnavirus etc. With the advent of next generation sequencing approaches the list of new enteric viruses has expanded. Viruses like Cyclovirus, Kirkovirus and Anellovirus are the new members identified in equines recently. Close proximity of horses to human settlements and/or other domestic animals pretense the threat of infectious diseases spread to humans/animals and vice-versa. Therefore, horse diseases are not only of veterinary importance but also are among important factors for public health. Herein, we intend to appraise current status of key enteric viruses that cause diarrheic disorders in foals and horses.
* Corresponding author

E-mail: malikyps@gmail.com (Yashpal S. Malik)

Peer review under responsibility of Journal of Experimental Biology and Agricultural Sciences.

Production and Hosting by Horizon Publisher India [HPI] (http://www.horizonpublisherindia.in/).

All rights reserved.
All the article published by Journal of Experimental Biology and Agricultural Sciences is licensed under a Creative Commons Attribution-NonCommercial 4.0 International License Based on a work at www.jebas.org.

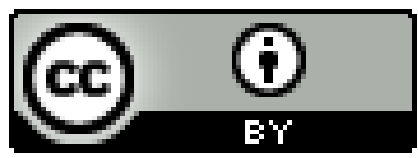




\section{Introduction}

Equines are among the earliest known mammalian species that have been incessantly domesticated by the human race since 4000 BC. Apart from being companion animals to humans, they have also been used as amusing or sporting animal. During late $19^{\text {th }}$ century, equine microbiology came under existence with the discovery of Burkholderia mallei as the feared pathogen of glanders and farcy of horse. Later on, a filterable agent was identified capable of causing African horse sickness (Slater, 2013). With the help of classic virological methods, numerous equine viruses have been added to this list such as equine influenza virus, West Nile virus, equid herpesviruses, equine encephalitis viruses, equine arteritis virus, equine infectious anemia virus, equine coronavirus, Hendra virus and vesicular stomatitis virus. Though, the study of equine infectious diseases has been an important part of veterinary sciences since ages, a large number of the equine diseases still remains unfamiliar. Close proximity of horses to human settlements and to other domestic animals pose the threat of infectious diseases spread to humans/animals and vice-versa. Zoonotic pathogens such as Alphaviruses, Hendra virus, Influenza A virus, Rabies virus and West Nile virus are reported to infect horses (Johnson, 2011; Cullinane \& Newton, 2013; Onmaz et al., 2013; Slater, 2013). It is therefore noteworthy that horse diseases are not only of veterinary importance but also pose potential threat of zoonosis/reverse zoonosis (Khurana et al., 2015; Mukarim et al., 2015) and are among important factors from human public health perspective.

Several enteric pathogens leading to multifactorial diseases have been detected and isolated from diseased foals and horses. The major enteric pathogens associated with neonatal foal diarrhea are rotavirus, coronavirus, Clostridium perfringens type A, Salmonella spp., Rhodococcusequiand Clostridium difficile (Fielding et al., 2015; Franco Ayala \& Oliver Espinosa, 2015; Barr, 2016). Foals co-infecting with number of infectious agents has also been documented in diarrheic foals (Slovis et al., 2014). One of the prime causes of equine enteritis is the viral infections. A recent metagenomics study highlighted several new viruses like Cyclovirus, Kirkovirus and Anellovirus along with known enteric viruses such as parvovirus, adenoviruses, coronaviruses, rotaviruses and picobirnaviruses in equines ( $\mathrm{Li}$ et al., 2015). In last few years, several reviews appeared on various aspects of equine health excluding enteric viral pathogens of equines, except a few that highlighted coronavirus and rotavirus infections in equines (Bailey et al., 2013; Papp et al., 2013; Dhama et al., 2014; Pusterla et al., 2015a). Viral etiological agents which are able to cause diarrheic outbreaks are comprehended in Table 1. In the event of emergence of several new viral infections worldwide including Ebola and Zika (Dhama et al., 2015a; Singh et al., 2016) there is urgent need to understand the burden of viral infections in different animal hosts. Here, we intend to review current status of major enteric viruses of economic importance that cause diarrheic disorders in foals and horses. Furthermore, current updates in the rotavirus and coronavirus infection in equines are covered.

\section{Adenovirus}

Adenoviruses belong to the Adenoviridae family, are unenveloped and have icosahedral nucleocapsid, with 90-100 nm size, encapsulating a dsDNA genome of $26-45 \mathrm{Kbp}$ (Davison et al., 2003). Adenoviruses are known to affect a wide vertebrate's host range and are genetically/antigenically heterogeneous (Harrach et al., 2011). Presently, this family comprises of 5 genuses as Mastadenovirus, Atadenovirus, Aviadenovirus, Ichtadenovirus and Siadenovirus (Harrach et al., 2011).

Horses and foals are affected by adenoviruses of genera Mastadenovirus, have been primarily connected with respiratory and gastrointestinal tract infections (Reubel \& Studdert, 1997; Cavanagh et al., 2012). Equine adenoviruses are separated into 2 serotypes and consequent molecular and phylogenetic readings established them as distinct species which are nowadays called as Equine adenovirus 1 (EAdV-1) and Equine Adenovirus 2 (EAdV-2) (Reubel \& Studdert, 1997; Cavanagh et al., 2012). Out of these two, EAdV-1 is primarily associated with infections in the respiratory tract of young foals and horses whereas EAdV-2 has been reported mainly from horses having diarrheal illness (Studdert \& Blackney, 1982). The first equine adenovirus was reported and isolated in USA (Todd, 1969) it was followed by isolation reports from Germany and Australia whereas physical characterization of the virus was published in 1973 of an adenovirus isolated from the pneumonic lung tissue of an Arabian foal (Ardans et al., 1973).

Antibodies pertaining to both the Equine Adenovirus types were reported in New South Wales, Australia (Giles et al., 2010). In a study during 1982 on the diarrheal outbreaks in young foals, researchers isolated and identified an Equine adenovirus strain which did not contain the hemagglutinationinhibiting antibody to EAdV-1 (Studdert \& Blackney, 1982). Similar research findings were published in New Zealand revealing two serologically different EAdV strains isolated from thoroughbred foals suffering from diarrhea and respiratory disease (Horner \& Hunter, 1982). These research findings supported the assumption that adenoviruses found in the fecal specimens should be considered as the prototype for EAdV-2. Compared to EAdV-1 adenovirus there has been less studies done with respect to EAdV-2 adenovirus with the very first sequence data appeared on the GenBank database for EAdV-2 in the year 1997 (Reubel \& Studdert, 1997) (GenBank L80007.1). The study by Ruebel and Studdert also established the first molecular evidence that EAdV-2 is distinct to EAdV1 , not only in antigenic aspect but is quite different on molecular level too. 
Table 1 Enteric viruses reported in equines having relevance in causing enteritis highlighting their main features.

\begin{tabular}{|c|c|c|c|c|c|c|}
\hline $\begin{array}{l}\text { SI } \\
\text { No. }\end{array}$ & Viruses & Genome & Genus & Species/serotypes & $\begin{array}{c}\text { Relevance in } \\
\text { enteric diseases }\end{array}$ & References \\
\hline \multirow[t]{2}{*}{1.} & Adenoviruses & dsDNA & Mastadenovirus & Equine Adenovirus 1 & No & $\begin{array}{l}\text { Cavanagh et } \\
\text { al.(2012) }\end{array}$ \\
\hline & & & & Equine Adenovirus 2 & Yes & Giles et al. (2015) \\
\hline 2. & Coronaviruses & ssRNA & Betacoronavirus & Betacoronavirus-1 & Yes & $\begin{array}{l}\text { Nemoto et al. } \\
(2015 b)\end{array}$ \\
\hline 3. & Rotaviruses & dsRNA & Rotavirus A & $\begin{array}{l}\text { G3P[12], G14P[12], G3P[3], } \\
\text { G5P[7], G6P[1], G8P[1], } \\
\text { G10P[1], G10P[11] and } \\
\text { G13P[18] }\end{array}$ & Yes & $\begin{array}{l}\text { Ghosh \& } \\
\text { Kobayashi (2014) }\end{array}$ \\
\hline 4. & Picobirnavirus & dsRNA & Picobirnaviruses & Equine picobirnavirus & Yes & Li et al. (2015) \\
\hline 5. & Parvovirus & ssDNA & Copiparvovirus & Ungulate Copiparvovirus 3 & No & Li et al. (2015) \\
\hline 6. & Anellovirus & ssDNA & Mutorquevirus & Unclassified & No & Li et al. (2015) \\
\hline 7. & Cyclovirus & ssDNA & Cyclovirus & Unclassified & No & Li et al. (2015) \\
\hline
\end{tabular}

A whole genome characterization of an EAdV-2 strain was also reported recently in the year 2015 in Australia (Giles et al., 2015) (GenBank Acc. No. KT160425). Interestingly, till this review in September 2016 there were only 2 sequence report available for EAdV-2 in the GenBank database out of which one is complete genome and another is $5.5 \mathrm{kbp}$ in length comprising the hexon and endopeptidase genes.

Unlike EAdV-1, which can be easily isolated and grows fastidiously in primary tissue culture derived from equine fetal kidney (EFK) cells (Studdert, 1978), EAdV-2 responds very poorly to cell culture and has been infrequently isolated (Horner \& Hunter, 1982; Studdert \& Blackney, 1982). The major technique used for the diagnosis and characterization of adenovirus is PCR which is based on the hexon gene of adenovirus genome which contains highly conserved regions (Reubel \& Studdert, 1997).

With the available literature regarding the infection of adenovirus in equines EAdV-1 has been studied widely in comparison to EAdV-2. Despite the significant improvement in the development of diagnostic techniques there has been scarcity of information regarding EAdV-2 which requires the attention of veterinarians and scientist working in the field of equine infectious diseases.

\section{Coronavirus}

Coronavirus is an enveloped, ssRNA, positive sense virus having a helical symmetry with a genome length of 26 to 32 $\mathrm{Kb}$, which is largest among the RNA viruses. The Coronaviridae family is divided into 2 subfamilies (Torovirinae and Coronavirinae). The later subfamily classified into four different genera viz. Alphacoronavirus, Betacoronavirus, Deltacoronavirus and Gammacoronavirus based on the serological and molecular differences (Woo et al., 2012). These are mainly associated with respiratory, neurologic, hepatic or gastrointestinal disorders in animals
(Holmes, 2001). The different animals reported to have Coronavirus mediated infections are swine, cattle, horse, dog, cat and avian species like chicken and turkey (Saif et al., 1991; White \& Fenner, 1994; Studdert, 1996; Jamieson et al., 1998; Guy et al., 2000; Lai \& Holmes, 2001; McIntosh, 2002; Strauss \& Strauss, 2002; Ksiazek et al., 2003; Van der Hoek et al., 2004; Brian \& Baric, 2005; Weiss \& Navas-Martin, 2005; Decaro \& Buonavoglia, 2008; Boileau \& Kapil, 2010; Woo et al., 2012).

Further, based on the antigenic properties coronaviruses are divided into 3 major antigenic groups which infect several animal hosts and humans (group 1 and 2) and also avian species (group 2). The group 1 comprise of human coronavirus (strain 229E), canine coronavirus, porcine transmissible gastroenteritis virus and feline infectious peritonitis virus. The group 2 is represented by human coronavirus strains (OC43 and HKU1), murine hepatitis virus, bovine coronavirus, porcine hemagglutinating encephalomyelitis virus, canine respiratory coronavirus (Erles et al., 2007), and bubaline coronavirus (Decaro et al., 2010). Viruses such as turkey coronavirus and infectious bronchitis virus are included in group 3 (Resta et al., 1985; Studdert, 1996; Davis et al., 2000; Guy et al., 2000; Lai \& Holmes, 2001; McIntosh, 2002; Strauss \& Strauss, 2002; Van der Hoek et al., 2004; Smith \& Denison, 2012; Woo et al., 2012; Smith et al., 2013).

The earliest known Equine Coronavirus (ECoV) recognized by electron microscopy (EM) in the foals diarrheic fecal samples and adult horses (Bass \& Sharpee, 1975; Huang et al., 1983). Later, in 2000 Davis and colleagues developed an antigen capture ELISA for the detection ECoV in the feces of diarrheic foal along with immunohistochemistry of affected foal's intestine suffering from neonatal enterocolitis (Davis et al., 2000). In the same year, an ECoV strain NC99 was isolated and its $\mathrm{N}$ protein gene was characterized using the previously described BCoV primers (Guy et al., 2000). The ECoVs have been found highly related with bovine coronaviruses (Imagawa 
et al., 1990; Guy et al., 2000). Subsequently, the complete genomic constellation of ECoV (strain NC99) was achieved which consists of 2 replicase polyproteins, 4 accessory proteins (ns2, p4.7, p12.7, and I) and 5 structural proteins viz. spike, hemagglutinin esterase, membrane, envelope and nucleocapsid (Zhang et al., 2007).

Diagnosis of coronaviruses has been routinely done through EM in the earlier times (Reed et al., 1983; Biermann et al., 1991; Guy et al., 2000). Using BCV antibodies serum neutralization tests has also been employed to detect ECoV infections in horses (Bass \& Sharpee, 1975; Imagawa et al., 1990; Anzai et al., 2001). Molecular techniques like nested PCR and quantitative PCR have been actively used in the diagnosis of ECoV (Guy et al., 2000; Slovis et al., 2010). During early stages of infection highly sensitive technique like real-time RT-PCR has been used (Pusterla et al., 2013; Miszczak et al., 2014). In 2015, a RT-LAMP was also developed for the isothermal detection of ECoV which can be economical in comparison to other diagnostic tests (Nemoto et al., 2015a). Recently a one-step real time RT-PCR was also developed and demonstrated for the sensitive detection of ECoV in respiratory and fecal samples (Miszczak et al., 2016). Improving the specificity of the detection one ELISA was recently developed for the specific detection of $\mathrm{ECoV}$ in naturally infected horses and record the seroprevalence in them (Kooijman et al., 2016).

In earlier studies, ECoV was suspected to cause enteritis in foals but their pathogenicity in young foals remained unproven (Davis et al., 2000; Van der Hoek et al., 2004; Arguedas, 2007). Mainly the tissue tropism for ECoV infections have been found to be inside the gastrointestinal tract of young foals and horses (Miszczak et al., 2014; Fielding et al. 2015; Pusterla et al., 2015b). Multiple ECoV outbreaks have occurred in the ÜSA and Japan (Oue et al., 2011; Oue et al., 2013; Pusterla et al., 2013). Besides the possible respiratory and mechanical transmission of coronaviruses in equines, infections spreads through fecal-oral route (Studdert, 1996; Anzai et al., 2001). Although, signs of upper respiratory tract infections are predominant with $\mathrm{ECoV}$ infected foals but their infrequent detection in nasal secretions shows their lack of tropism to the upper respiratory tract of young horses. In an experimental study on Japanese draught horses, the horses were experimentally inoculated with ECoV strain NC99 and Obihiri 12-2 to confirm and investigate the clinical signs and virus shedding pattern of $\mathrm{ECoV}$ in horses.

Though, nasal secretions came positive in PCR assay, experiments could not define whether this was due to nasal replication of the virus and subsequent shedding or due to environmental factors or both (Nemoto et al., 2014). Subsequently, in 2015 a study reported the whole genome sequencing of three earlier isolated ECoV strains from Japan Obihiri 12-1, Obihiri 12-2 and Tokachi09. The study found the three strains genetically similar to NC99 strains of USA with minor exceptions in NS2, NSP3 and p4.7 genes (Nemoto et al., 2015b).
It has been usually observed that ECoV infection in horses spread when they are sheltered together, which has been confirmed by the presence of $\mathrm{BCoV}$ and other related coronavirus antibodies in the feces of horses (Imagawa et al., 1990; Anzai et al., 2001). Better management practices regarding the sheltering and transit of young foals and adult horses can arrest the infection from spreading to other places.

\section{Rotaviruses}

Rotaviruses are the foremost cause of diarrhea in neonates of humans, animals and avian (Estes \& Kapikian, 2007; Dhama et al., 2015b). Till date, nine different species have been identified in rotaviruses from (A-I) as per the antigenic differences in the major inner capsid protein and nucleotide sequence identities gene encoding the VP6 protein (Matthijnssens et al., 2012a; Mihalov-Kovacs et al., 2015), although recently reported species I needs further endorsement by the ICTV. Rotaviral genome is made up of eleven dsRNA segments that encode 6 structural proteins viz; VP1, VP2, VP3, VP4, VP6 \& VP7 and 5/6 non-structural proteins i.e. NSP1NSP5/6). The major coat proteins (VP4 \& VP7) induce the neutralizing antibodies production and are considered important due to the genetic classification which is based on these genes. As per the latest update of Rotavirus Classification Work Group (RCWG) till $27^{\text {th }}$ June, 2016 there are 32 G-genotypes (VP7) and 47 P-genotypes (VP4) reported in various host species (https://rega.kuleuven.be/cev/viralmetagenomics/virusclassification/ rcwg).

Among all the species of rotavirus, only group A rotaviruses (RVA) has been detected in the equines so far (Matthijnssens et al., 2012b). The first detection of equine RV has been reported in the year 1975 from England (Flewett et al., 1975). Since from this, equine RVs have been known to be the major causes of diarrhea in foals (Imagawa et al., 1991; Collins et al., 2008; Frederick et al., 2009). Based on the serological reports equine RVAs have been shown to be ubiquitous in the equine populations (Pearson et al., 1982).

Numbers of diagnostic techniques have been employed for detecting RVs in diarrheic foals and adult horses. Electron microscopy was the first technique to be applied for the identification of RVs in foals but unfortunately it requires costly instruments and expertise. Moreover the diagnostic sensitivity of EM turns out to be very low as it can't detect virus particles lower than $10^{7} \mathrm{per} \mathrm{ml}$ of stool samples (McIntosh, 1996). Culturing the RV in cell line is again a daunting task. Equine RV has been isolated in MA-104 cell line in the year 1981 when field sample from a diarrheic foal has been successfully adapted in UK (Imagawa et al., 1981). RNA-PAGE has been widely applied for the detection of equine RVs due to the peculiarity of different RV groups to migrate differently on the RNA-PAGE. Certain studies has reported the typical migration pattern being observed with equine RVA isolates with the segment 3 \& 4 migrating together close to each other and unlike the other RVA isolates 
here the segment 7,8 and 9 migrate as a triplet (Hardy et al., 1991).

ELISA and other immunodiagnostic have been now used for rapid detection of $\mathrm{RV}$ which are usually based on the group specific VP6 gene product (outer coat protein). Many test kits available for human RV detection has also been employed in the detection of equine rotaviruses, though the sensitivity of ELISA has been found more in respect to other immunodiagnostic test (Nemoto et al., 2010a). The indication of widespread RVA infections in horses was evident by the finding of RVA specific antibodies in adult horses (Pearson et al., 1982; Eichhorn \& Huan-Chun, 1987). It was also evident by the detection of RVA in equine population from different countries which includes the United Kingdom (Strickland et al., 1982), the United States of America (Kanitz, 1977), Australia (Studdert et al., 1978; Tzipori \& Walker, 1978) Germany (Elschner et al., 2005), New Zealand (Durham et al., 1979; Schroeder et al., 1983), France (Puyalto-Moussu \& Taouji, 2002), Greece (Ntafis et al., 2010), Italy (Monini et al., 2011), the Netherlands (Van der Heide et al., 2005), Argentina (Barrandeguy et al., 1998), Venezuela (Ciarlet et al., 1994) and India (Gulati et al., 2009).

RT-PCR assays are being used as test of choice nowadays for the detection as well as for genotyping of equine RVA strains (Gouvea et al., 1994; Tsunemitsu et al., 2001; Garaicoechea et al., 2011). Hybridizing probe based diagnostics and genotyping has also been attempted in bovine rotavirus which can be opted for equine strains too (Minakshi et al., 2005). More recently, one isothermal technique RT-LAMP has been developed targeting the VP4 with P[12] specificity (Nemoto et al., 2010b). Moreover, in USA RT-PCR kit is commercially available for early and quick detection of RVs (Slovis et al., 2010). As submissions of molecular sequence of rotavirus have been increased in public database, sequence based typing of rotavirus groups got interest. Till now, there have been 6 Ggenotypes (Imagawa et al., 1994; Isa et al., 1994; Isa et al., 1996) and 6 P-genotypes (Garaicoechea et al., 2011) are reported in equines (Table 2).

Table $2 \mathrm{G}$ and $\mathrm{P}$ genotypes of equines rotaviruses reported till date.

\begin{tabular}{|ll|}
\hline G-Type & P-Type \\
\hline G3 & $\mathrm{P}[1]$ \\
\hline G5 & $\mathrm{P}[3]$ \\
\hline G8 & $\mathrm{P}[7]$ \\
\hline G10 & $\mathrm{P}[11]$ \\
\hline G13 & $\mathrm{P}[12]$ \\
\hline G14 & $\mathrm{P}[18]$ \\
\hline
\end{tabular}

Among the widely reported and commonly found genotype combinations of equine RVA, G3P[12] and G14P[12] have been described several times worldwide (Tsunemitsu et al., 2001; Elschner et al., 2005; Collins et al., 2008; Ntafis et al., 2010; Garaicoechea et al., 2011; Nemoto et al., 2011 Papp et al., 2013). The G3 RVA strains have been further differentiated into 2 subtypes (G3A and G3B) as per reactivity with monoclonal antibodies (Browning et al., 1992). In the year 1991, a highly unfamiliar equine RVA stain (L338) carrying G13P[18] genotype combination was reported from UK (Browning et al., 1991a). Using the RNA-RNA hybridization technique, it was shown that the strain L338 possess a distinctive genotype of G13 and P[18] and unusual NSP1 genetic makeup which found distinct to other human and animal RVAs (Wu et al.,1993; Taniguchi et al., 1994; Kojima et al., 1996). Certain bovine-like equine RVAs have also been reported which are highly similar to bovine RV strains employing labeled probes and RNA-RNA hybridization techniques from UK and Japan, respectively (Imagawa et al., 1991; Imagawa et al., 1993; Isa et al., 1996),

Similarly, an unusual G6 and G10P6[1] rotavirus was detected in equines between 2003 and 2005 in addition to G1 strains from India, but later this report was taken back following the wrong classification of G6 RVA strains as G16 (Matthijnssens et al., 2012b). In Argentina also an uncommon feline-like RVA was also reported in diarrheic foal (Garaicoechea et al., 2011). Certain unusual equine RVA genotype combinations has also been discovered such as G3P[3], G5P[7], G6P[1], G8P[1], G10P[1], G10P[11] and G13P[18], (Gulati et al., 2007; Garaicoechea et al., 2011). Till date only three inactivated equine RVA vaccine have developed by Argentina, Japan and USA and are being used in several countries contains the common genotype of G3P[12] strain (Imagawa et al., 2005).

During three decades (1981-2010) there have been several studies in Japan leading to the genetic analysis and characterization of equine RVAs (Takagi et al., 1994; Tsunemitsu et al., 2001; Fukai et al., 2006; Nemoto et al., 2012;). Till 2013 only few reports for the whole genome characterization and analysis of equine RVA strains have been documented (Ghosh et al., 2012; Matthijnssens et al., 2012b; Mino et al., 2013). The strains characterized for their complete genomic constellations were three from Europe (Strain: L338; 03V04954 and 04V2024), three from Argentina (Strain: E30; E403 and E4040), one from South Africa (Strain: EqRV-SA1) and four from Japan (Stain: B1; HH-22; CH-3 and OH-4) (Ghosh et al., 2012; Matthijnssens et al., 2012b; Ghosh et al., 2013; Mino et al., 2013).

In February 2015, a report appeared in which 23 equine RVA strains from late 1990s and 2009-2010 along with the vaccine strain HO-5 were characterized through the next generation sequencing (Nemoto et al., 2015c) taking the total count of whole genome reports for equine RVA to 37 isolates till dates (Table 2). In the whole genome and further phylogenetic analysis of 37 isolates revealed that the G3 strains carried a uniform genetic constellation for their 11 gene segments and were closely related to the HO-5 vaccine strain irrespective of time they were confirmed (Nemoto et al., 2015c). In disparity, the G14 strains showed some divergence in respect to VP7 and NSP4 gene. 
Figure 1 Whole genome backbone consisting of 11 segments of equine group A rotavirus (RVA) strains with known genomic constellations.

\begin{tabular}{|c|c|c|c|c|c|c|c|c|c|c|c|c|c|c|}
\hline SL. No & Strain Name & Year of Isolation & VP7 & VP4 & VP6 & VP1 & VP2 & VP3 & NSP1 & NSP2 & NSP3 & NSP4 & NSP5 & Reference \\
\hline 1 & RVA/Horse-wt/ARG/E403/2006/G14P[12] & 2006 & G14 & $\mathrm{P}[12]$ & $\mathrm{I} 2$ & $\mathrm{R} 2$ & $\mathrm{C} 2$ & M3 & $\mathrm{A} 10$ & $\mathrm{~N} 2$ & $\mathrm{~T} 3$ & E12 & $\mathrm{H} 7$ & Matthijnssens et al. (2012) \\
\hline 2 & RVA/Horse-wt/ARG/E4040/2008/G14P[12] & 2008 & G14 & $\mathrm{P}[12]$ & 12 & $\mathrm{R} 2$ & $\mathrm{C} 2$ & M3 & $\mathrm{A} 10$ & $\mathrm{~N} 2$ & $\mathrm{~T} 3$ & E12 & $\mathrm{H} 7$ & Matthijnssens et al. (2012) \\
\hline 3 & RVA/Horse-wt/ARG/E30/1993/G3P[12] & 1993 & G3 & $\mathrm{P}[12]$ & I6 & $\mathrm{R} 2$ & $\mathrm{C} 2$ & M3 & $\mathrm{A} 10$ & $\mathrm{~N} 2$ & $\mathrm{~T} 3$ & E12 & $\mathrm{H} 7$ & Matthijnssens et al. (2012) \\
\hline 4 & RVA/Horse-wt/IRL/03V04954/2003/G3P[12] & 2003 & G3 & $\mathrm{P}[12]$ & I6 & $\mathrm{R} 2$ & $\mathrm{C} 2$ & M3 & $\mathrm{A} 10$ & $\mathrm{~N} 2$ & $\mathrm{~T} 3$ & E2 & $\mathrm{H} 7$ & Matthijnssens et al. (2012) \\
\hline 5 & RVA/Horse-wt/IRL/04V2024/2004/G14P[12] & 2004 & G14 & $\mathrm{P}[12]$ & $\mathrm{I} 2$ & $\mathrm{R} 2$ & $\mathrm{C} 2$ & M3 & $\mathrm{A} 10$ & $\mathrm{~N} 2$ & $\mathrm{~T} 3$ & E2 & $\mathrm{H} 7$ & Matthijnssens et al. (2012) \\
\hline 6 & RVA/Horse-wt/ZAF/EqRV- & 2006 & G14 & $\mathrm{P}[12]$ & $\mathrm{I} 2$ & $\mathrm{R} 2$ & $\mathrm{C} 2$ & M3 & $\mathrm{A} 10$ & N2 & $\mathrm{T} 3$ & E2 & $\mathrm{H} 7$ & Matthijnssens et al. (2012) \\
\hline 7 & RVA/Horse-tc/GBR/L338/1991/G13P[18] & 1991 & G13 & $\mathrm{P}[18]$ & I6 & $\mathrm{R} 9$ & C9 & M6 & A6 & N9 & $\mathrm{T} 12$ & E14 & H11 & Matthijnssens et al. (2012) \\
\hline 8 & RVA/Horse-wt/ARG/E3198/2008/G3P[3] & 2008 & G3 & $\mathrm{P}[3]$ & $\mathrm{I} 3$ & $\mathrm{R} 3$ & $\mathrm{C} 3$ & M3 & A9 & N3 & $\mathrm{T} 3$ & E3 & H6 & Mino et al. (2013) \\
\hline 10 & RVA/Horse -tc/JPN/OH -4/1982/G6P[5] & 1982 & G6 & $\mathrm{P}[5]$ & $\mathrm{I} 2$ & $\mathrm{R} 2$ & $\mathrm{C} 2$ & M2 & A13 & $\mathrm{N} 2$ & T6 & E2 & $\mathrm{H} 3$ & Ghosh et al. (2013) \\
\hline 11 & RVA/Horse -tc/JPN/BI/1981/G3P[12] & 1981 & G3 & $\mathrm{P}[12]$ & $\mathrm{I} 2$ & $\mathrm{R} 2$ & $\mathrm{C} 2$ & M3 & $\mathrm{A} 10$ & $\mathrm{~N} 2$ & $\mathrm{~T} 3$ & E2 & $\mathrm{H} 7$ & Ghosh et al. (2013) \\
\hline 12 & RVA/Horse -tc/JPN/HH -22/1989/G 3P[12] & 1989 & G3 & $\mathrm{P}[12]$ & I6 & $\mathrm{R} 2$ & $\mathrm{C} 2$ & M3 & $\mathrm{A} 10$ & $\mathrm{~N} 2$ & $\mathrm{~T} 3$ & E2 & $\mathrm{H} 7$ & Ghosh et al. (2013) \\
\hline 13 & RVA/Horse -tc/JPN/CH -3/1987/G14P[12] & 1987 & G14 & $\mathrm{P}[12]$ & $\mathrm{I} 2$ & $\mathrm{R} 2$ & $\mathrm{C} 2$ & M3 & $\mathrm{A} 10$ & $\mathrm{~N} 2$ & $\mathrm{~T} 3$ & E2 & $\mathrm{H} 7$ & Ghosh et al. (2013) \\
\hline 14 & RVA/Horse-tc/JPN/HO-5/1982/G3P[12] & 1982 & G3 & $\mathrm{P}[12]$ & $\mathrm{I} 2$ & $\mathrm{R} 2$ & $\mathrm{C} 2$ & M3 & $\mathrm{A} 10$ & $\mathrm{~N} 2$ & $\mathrm{~T} 3$ & E2 & $\mathrm{H} 7$ & Nemoto et al. (2015c) \\
\hline 15 & RVA/Horse-tc/JPN/JE29/1997/G3P[12] & 1997 & G3 & $\mathrm{P}[12]$ & $\mathrm{I} 2$ & $\mathrm{R} 2$ & $\mathrm{C} 2$ & M3 & $\mathrm{A} 10$ & $\mathrm{~N} 2$ & $\mathrm{~T} 3$ & E2 & $\mathrm{H} 7$ & Nemoto et al. (2015c) \\
\hline 16 & RVA/Horse-tc/JPN/JE75/1997/G3P[12] & 1997 & G3 & $\mathrm{P}[12]$ & I2 & $\mathrm{R} 2$ & $\mathrm{C} 2$ & M3 & $\mathrm{A} 10$ & $\mathrm{~N} 2$ & $\mathrm{~T} 3$ & E2 & $\mathrm{H} 7$ & Nemoto et al. (2015c) \\
\hline 17 & RVA/Horse-tc/JPN/JE76/1996-1997/G3P[12] & 1996 & G3 & $\mathrm{P}[12]$ & I2 & $\mathrm{R} 2$ & $\mathrm{C} 2$ & M3 & A10 & $\mathrm{N} 2$ & $\mathrm{~T} 3$ & E2 & $\mathrm{H} 7$ & Nemoto et al. (2015c) \\
\hline 18 & RVA/Horse-tc/JPN/JE97/1996/G3P[12] & 1996 & G3 & $\mathrm{P}[12]$ & $\mathrm{I} 2$ & $\mathrm{R} 2$ & $\mathrm{C} 2$ & M3 & $\mathrm{A} 10$ & $\mathrm{~N} 2$ & $\mathrm{~T} 3$ & E2 & $\mathrm{H} 7$ & Nemoto et al. (2015c) \\
\hline 20 & RVA/Horse-tc/JPN/No.1/2010/G3P[12] & 2010 & G3 & $\mathrm{P}[12]$ & $\mathrm{I} 2$ & $\mathrm{R} 2$ & $\mathrm{C} 2$ & M3 & $\mathrm{A} 10$ & $\mathrm{~N} 2$ & $\mathrm{~T} 3$ & E2 & $\mathrm{H} 7$ & Nemoto et al. (2015c) \\
\hline 21 & RVA/Horse-tc/JPN/No.2/2010/G3P[12] & 2010 & G3 & $\mathrm{P}[12]$ & $\mathrm{I} 2$ & $\mathrm{R} 2$ & $\mathrm{C} 2$ & M3 & $\mathrm{A} 10$ & $\mathrm{~N} 2$ & $\mathrm{~T} 3$ & E2 & $\mathrm{H} 7$ & Nemoto et al. $(2015 \mathrm{c})$ \\
\hline 22 & RVA/Horse-tc/JPN/No.4/2010/G3P[12] & 2010 & G3 & $\mathrm{P}[12]$ & $\mathrm{I} 2$ & $\mathrm{R} 2$ & $\mathrm{C} 2$ & M3 & $\mathrm{A} 10$ & $\mathrm{~N} 2$ & $\mathrm{~T} 3$ & E2 & $\mathrm{H} 7$ & Nemoto et al. (2015c) \\
\hline 23 & RVA/Horse-tc/JPN/No.7/2010/G3P[12] & 2010 & G3 & $\mathrm{P}[12]$ & $\mathrm{I} 2$ & $\mathrm{R} 2$ & $\mathrm{C} 2$ & M3 & $\mathrm{A} 10$ & $\mathrm{~N} 2$ & $\mathrm{~T} 3$ & E2 & $\mathrm{H} 7$ & Nemoto et al. (2015c) \\
\hline 24 & RVA/Horse-tc/JPN/No.9/2010/G3P[12] & 2010 & G3 & $\mathrm{P}[12]$ & $\mathrm{I} 2$ & $\mathrm{R} 2$ & $\mathrm{C} 2$ & M3 & $\mathrm{A} 10$ & $\mathrm{~N} 2$ & $\mathrm{~T} 3$ & E2 & $\mathrm{H} 7$ & Nemoto et al. (2015c) \\
\hline 25 & RVA/Horse-tc/JPN/No.13/2010/G3P[12] & 2010 & G3 & $\mathrm{P}[12]$ & I2 & $\mathrm{R} 2$ & $\mathrm{C} 2$ & M3 & $\mathrm{A} 10$ & $\mathrm{~N} 2$ & $\mathrm{~T} 3$ & E2 & $\mathrm{H} 7$ & Nemoto et al. (2015c) \\
\hline 26 & RVA/Horse-tc/JPN/No.32/2010/G3P[12] & 2010 & G3 & $\mathrm{P}[12]$ & $\mathrm{I} 2$ & $\mathrm{R} 2$ & $\mathrm{C} 2$ & M3 & $\mathrm{A} 10$ & $\mathrm{~N} 2$ & $\mathrm{~T} 3$ & E2 & $\mathrm{H} 7$ & Nemoto et al. (2015c) \\
\hline 27 & RVA/Horse-tc/JPN/No.52/2009/G3P[12] & 2009 & G3 & $\mathrm{P}[12]$ & $\mathrm{I} 2$ & $\mathrm{R} 2$ & $\mathrm{C} 2$ & M3 & $\mathrm{A} 10$ & $\mathrm{~N} 2$ & $\mathrm{~T} 3$ & E2 & $\mathrm{H} 7$ & Nemoto et al. (2015c) \\
\hline 28 & RVA/Horse-tc/JPN/No.55/2009/G3P[12] & 2009 & G3 & $\mathrm{P}[12]$ & $\mathrm{I} 2$ & $\mathrm{R} 2$ & $\mathrm{C} 2$ & M3 & $\mathrm{A} 10$ & $\mathrm{~N} 2$ & $\mathrm{~T} 3$ & E2 & $\mathrm{H} 7$ & Nemoto et al. (2015c) \\
\hline 29 & RVA/Horse-tc/JPN/JE77/1997/G14P[12] & 1997 & G14 & $\mathrm{P}[12]$ & $\mathrm{I} 2$ & $\mathrm{R} 2$ & $\mathrm{C} 2$ & M3 & $\mathrm{A} 10$ & $\mathrm{~N} 2$ & $\mathrm{~T} 3$ & E2 & $\mathrm{H} 7$ & Nemoto et al. (2015c) \\
\hline 30 & RVA/Horse-tc/JPN/JE81/1997/G14P[12] & 1997 & G14 & $\mathrm{P}[12]$ & I2 & $\mathrm{R} 2$ & $\mathrm{C} 2$ & M3 & $\mathrm{A} 10$ & $\mathrm{~N} 2$ & $\mathrm{~T} 3$ & E2 & H7 & Nemoto et al. (2015c) \\
\hline 31 & RVA/Horse-tc/JPN/JE84/1996/G14P[12] & 1996 & G14 & $\mathrm{P}[12]$ & $\mathrm{I} 2$ & $\mathrm{R} 2$ & $\mathrm{C} 2$ & M3 & $\mathrm{A} 10$ & $\mathrm{~N} 2$ & $\mathrm{~T} 3$ & E2 & $\mathrm{H} 7$ & Nemoto et al. (2015c) \\
\hline 32 & RVA/Horse-tc/JPN/JE87/1996-1997/G14P[12] & 1996 & G14 & $\mathrm{P}[12]$ & $\mathrm{I} 2$ & $\mathrm{R} 2$ & $\mathrm{C} 2$ & M3 & $\mathrm{A} 10$ & $\mathrm{~N} 2$ & $\mathrm{~T} 3$ & E2 & $\mathrm{H} 7$ & Nemoto et al. (2015c) \\
\hline 33 & RVA/Horse-tc/JPN/JE115/1997/G14P[12] & 1997 & G14 & $\mathrm{P}[12]$ & $\mathrm{I} 2$ & $\mathrm{R} 2$ & $\mathrm{C} 2$ & M3 & $\mathrm{A} 10$ & $\mathrm{~N} 2$ & $\mathrm{~T} 3$ & E2 & $\mathrm{H} 7$ & Nemoto et al. (2015c) \\
\hline 34 & RVA/Horse-tc/JPN/No.24/2010/G14P[12] & 2010 & G14 & $\mathrm{P}[12]$ & $\mathrm{I} 2$ & $\mathrm{R} 2$ & $\mathrm{C} 2$ & M3 & $\mathrm{A} 10$ & $\mathrm{~N} 2$ & $\mathrm{~T} 3$ & E2 & $\mathrm{H} 7$ & Nemoto et al. (2015c) \\
\hline 35 & RVA/Horse-tc/JPN/No.28/2010/G14P[12] & 2010 & G14 & $\mathrm{P}[12]$ & $\mathrm{I} 2$ & $\mathrm{R} 2$ & $\mathrm{C} 2$ & M3 & $\mathrm{A} 10$ & $\mathrm{~N} 2$ & $\mathrm{~T} 3$ & E2 & $\mathrm{H} 7$ & Nemoto et al. (2015) \\
\hline 36 & RVA/Horse-tc/JPN/No.29/2010/G14P[12] & 2010 & G14 & $\mathrm{P}[12]$ & $\mathrm{I} 2$ & $\mathrm{R} 2$ & $\mathrm{C} 2$ & M3 & $\mathrm{A} 10$ & $\mathrm{~N} 2$ & $\mathrm{~T} 3$ & E2 & $\mathrm{H} 7$ & Nemoto et al. (2015c) \\
\hline 37 & RVA/Horse-tc/JPN/No.50/2010/G14P[12] & 2010 & G14 & $\mathrm{P}[12]$ & $\mathrm{I} 2$ & $\mathrm{R} 2$ & $\mathrm{C} 2$ & M3 & $\mathrm{A} 10$ & $\mathrm{~N} 2$ & $\mathrm{~T} 3$ & $\mathrm{E} 2$ & $\mathrm{H} 7$ & Nemoto et al. (2015c) \\
\hline
\end{tabular}


The NSP4 gene of G14 strains and also G3 strains clustered along with bovine RVAs and bovine-like equine strain $\mathrm{OH}-4$ and $\mathrm{HH}-22$, whereas rest all other genes were identical to HO5 vaccine strain (Nemoto et al., 2015c). The common backbone of the equine RVAs has been shown in Table 2 comprising all the whole genome isolates.

Almost all the common whole genome equine RVA strains characterized previously showed conserved genotypic constellation among them and were divergent in nature to the other RVA isolates (Matthijnssens et al., 2012b). Whereas few equine RVA strains characterized showed unique genetic makeup and elaborated the possibility of interspecies jumping of RVAs from one species to the other (Figure 1). The strains showing the possibility of interspecies transmission were equine G3P[18] RVA strain L338 (Matthijnssens et al., 2012b), H-1 strain believed to be transmitted from pigs to equines (Ghosh et al., 2012), whereas strain E3198 seemed to be resultant of canine/feline RVA strain to equines (Mino et al., 2013). Further, strengthening the need to analyze more common and uncommon equine RVA strains around the world the analysis done by two research groups were remarkable (Matthijnssens et al., 2012b; Ghosh et al., 2013). These reports established the fact that more or less out of the 11 segments of RVAs the interspecies transmission event are constantly changing the nature of equine RVA being detected in the horse population worldwide. While a report from UK reported that the strain L338 has no closeness with any other rotavirus and thus confirms that few strains remains solely adaptable to equine with no sign of interspecies transmission (Ciarlet et al., 2001).

Although out of the eleven segments of RVA, eight showed the conserved nature among the equine RVAs, whereas only VP6, VP7 and NSP4 genes showed existence of 2 diverse genotypes: I2/I6, G3/G14 and E2/E12, respectively. These reports also hypothesized the presence of distinguished lineages present among the common equine genotype constellations. At least three lineages of equine genomic constellation are circulating among equine rotaviruses since 1990s including G3-P[12]-I6-E2 lineage I, G14-P[12]-I2-E2 lineage I, and G14-P[12]-I2-E2 lineage II (Nemoto et al., 2015c). Though these lineages are interim therefore more complete information will be needed to decipher the relationship of these lineages. Unusually the three complete genome reports of equine RVA from Argentina showed the presence of E12 NSP4 genotype which were recently recovered from guanacos and the unusual bovine RVA strain (G15P[11]) from Argentina (Matthijnssens et al., 2009).

Further, this E12 genotype was also detected in all analyzed isolates from 1998 to 2008 in Argentinian foals (Garaicoechea et al., 2011). Certain unpublished data also shown the incidence of E12 NSP4 genotype in Argentinean goat and cattle population. But it was surprising to find that NSP4 E12 genotype is only confined to equine RVA strains to much of extent which may be the success indicator of quarantine procedures involved in the transportation of horses which restricted its transmission to other continents. But no such geographical barrier is present between the African and European equine RVA strains as two strains (04V2024 and EqRV-SA1) shared nearly identical genotype G14P[12] identified in South Africa and Ireland, respectively.

Presence of bovine RVA like NSP4 gene in conserved equine backbone from Japan points towards the probability of equine rotavirus as an acceptor of gene segments from different host species and vice-versa (Nemoto et al., 2015b). Detection of equine origin G3 genotype of VP7 in humans from Asia, Australia and Europe confirms the possible host species jump event of equine rotavirus to human hosts (Malasao et al., 2015; Cowley et al., 2016). Lately, similar reports emerged from Spain and Hungary concerning the emergence of unusual G3P[8] type rotaviruses in humans wherein the VP7 gene represents an equine like G3 (Arana et al., 2016; Dóró et al., 2016). These evolutionary phenomenon i.e. reassortment and species jumping leads to rotavirus genetic diversity which eventually pose a threat to human and other animal host species. Therefore, a more rigorous surveillance programs are prerequisite to establish geographical relationship among the equine rotavirus strains.

\section{Picobirnavirus}

Picobirnaviruses (PBVs) are small, un-enveloped viruses containing bi-segmented dsRNA genome. They contains $\sim 2.5$ kbp segments 1 and $\sim 1.7 \mathrm{kbp}$ for the segment 2 (Malik et al., 2014). The segment I encodes for the single structural capsid protein gene and segment 2 encodes the viral RNA polymerase (RdRp). It is placed in a new viral family namely Picobirnaviridae and is assigned a new taxonomic order which contains a single genus Picobirnavirus. The genus include only two species i.e. Human Picobirnavirus and Rabbit Picobirnavirus (Malik et al., 2014). The human PBV serves as the type species whereas the rabbit PBV serves as the designated species according to the ICTV. Based on the RdRp gene segment 2, PBVs are grouped into 2 genogroups (genogroup-I and II). Recent studies also proposed possible new genogroup namely III, IV and V based on the diversity of RdRp sequences (Smits et al., 2014; Li et al., 2015). The proposed new groups include strains from human (group III and V), dromedary (group V) and equine (group IV and V). Equine PBV strains have been identified in horse blood plasma (Li et al., 2015).

With the advancement of molecular diagnostic techniques such as RT-PCR (Ganesh et al., 2012; Malik et al., 2013; Takiuchi et al., 2016) and qRT-PCR (Malik, unpublished data) for picobirnaviruses, they have been detected in faecal and respiratory samples from over 20 animal species including rodents, aves and large animals like rats, hamsters, guinea pigs, giant ant eater, dogs, pigs, bovine calves, buffalo calves, foals camels, snakes worldwide and exhibit vast genetic diversity (Ganesh et al., 2011; Malik et al., 2011; Smits et al., 2011; Gillman et al., 2013; Malik et al., 2013; Malik et al., 2014; Ng et al., 2014; Ribeiro et al., 2014; Woo et al., 2014, Verma et 
al., 2015; Takiuchi et al., 2016). Despite the broad host range, pathogenicity of PBVs alone or as co-infecting agents remains unclear.

In equines, PBVs have been reported for the first time in the year 1991 in foals in Ireland and Britain (Browning et al., 1991b), followed by the RT-PCR detection in a female foal from Kolkata, India (Ganesh et al., 2011). Recently, equine PBVs co-infections were detected in plasma of a horse showing depression, loss of appetite (Li et al., 2015). Sequence analysis of viral RdRp and capsid genes showed four highly diverse picobirnaviruses including a novel fused picobirnavirus genome. These few reports of equine PBVs deserves attention regarding their epidemiological study and towards the development of diagnostic tools.

\section{Miscellaneous Enteric Viral Infections}

Several other viruses have also been shown to induce diarrhea like symptoms in neonatal or young foals but their relevance to enteritis less studied. Parvovirus in animals is usually known for its diarrheal symptoms but in equines it is reported in aborted equine fetus (Wong et al., 1985). Of late, parvovirus was recorded in cerebrospinal fluid (CSF) of a horse exhibiting neurological signs ( $\mathrm{Li}$ et al., 2015). The study also enlist some other enteric viruses with no relevance to enteritis in equine namely anelloviruses, cyclovirus, kirkovirus etc. The scanty data on these viruses especially in equines is still lacking.

\section{Conclusion}

Many diseases have their multifactorial causes with different symptoms and etiologies. A peculiar type of immune response is prompted by a particular pathogen whereas, other coinfecting pathogens make it complex. In veterinary medicine, the documentation of GIT infections with co-infecting pathogens has not been well studied. Especially in equines, the knowledge of co-infections is very scarce. Different enteric viruses have different symptoms and their spread can be controlled by better diagnosis and intensive care of the foals. Prognosis for a young foal with diarrhea varies according to the causative virus and hence the severity of clinical signs also changes.

Apart from vaccine development other options such as herbal preparations can be also tried as potential preventive alternative. Since enteric infections are a big challenge worldwide we need to explore better preventive options available as anything might prove efficient and miraculous in preventing these infection in days to come. For inactivation of the environmental contamination through virus shedding, proper disinfectants must be opted as well as selection of better hand sanitizers must be taken care. Therefore, better management practices, nutritional management, diagnosis and treatment strategy according to the causative virus is important for the equine health.

\section{Acknowledgments}

All the authors acknowledge their thanks for support to their respective institutions and universities.

\section{Conflict of interest}

Authors would hereby like to declare that there is no conflict of interests that could possibly arise.

\section{References}

Anzai T, Fukunaga Y, Matsumura T, Imagawa H, Oikawa MA (2001) Serological Examination for Viral Infection among Young Racehorses Transported by Vehicle over a Long Distance. Journal of Equine Science 12: 135-137. DOI: 10.1294/jes. 12.135

Arana A, Montes M, Jere KC, Alkorta M, Iturriza-Gómara M, Cilla G (2016) Emergence and spread of G3P [8] rotaviruses possessing an equine-like VP7 and a DS-1-like genetic backbone in the Basque Country (North of Spain), 2015. Infection, Genetics and Evolution 44: 137-144.

Ardans A, Pritchett RF, Zee YC (1973) Isolation and characterization of an equine adenovirus. Infection and Immunity 7: 673-677.

Arguedas MG (2007) Coronavirus Infections: Equine Coronavirus. In: Sellon DC, Long MT (Eds.) Equine Infectious Diseases, Elsevier, Philadelphia, USA.

Bailey KE, Gilkerson JR, Browning GF (2013) Equine rotaviruses-Current understanding and continuing challenges. Veterinary Microbiology 167: 135-144.

Barr B (2016) Nutritional management of the foal with diarrhoea. Equine Veterinary Education DOI: 10.1016/j.vetmic.2013.07.010

Barrandeguy M, Parreno V, Lagos M, Lezica F Pont, Rivas C, Valle C, Fernandez F (1998) Prevention of rotavirus diarrhoea in foals by parenteral vaccination of the mares: field trial. Developments in Biological Standardization 92: 253-257.

Bass EP, Sharpee RL (1975) Coronavirus and gastroenteritis in foals. The Lancet 2: 822 .

Biermann U, Schmitt K, Krauss H (1991) Electron microscopic virus diagnosis in dogs, cats, calves, swine and foals in the year 1989. Berliner Und Munchener Tierarztliche Wochenschrift 104: 117-119.

Boileau MJ, Kapil S (2010) Bovine coronavirus associated syndromes. Veterinary Clinics of North America. Food Animal Practice 26: 123-146. DOI: 10.1016/j.cvfa.2009.10.003 
Brian DA, Baric RS (2005) Coronavirus Genome Structure and Replication. In: Coronavirus Replication and Reverse Genetics, Springer, Berlin, Heidelberg

Browning GF, Chalmers RM, Fitzgerald TA, Snodgrass DR (1991a) Serological and genomic characterization of L338, a novel equine group A rotavirus $\mathrm{G}$ serotype. Journal of General Virology 72: 1059-1064.

Browning GF, Chalmers RM, Fitzgerald TA, Snodgrass DR (1992) Evidence for two serotype G3 subtypes among equine rotaviruses. Journal of Clinical Microbiology 30: 485-491.

Browning GF, Chalmers RM, Snodgrass DR, Batt RM, Hart CA, Ormarod SE, Leadon D, Stoneham SJ, Rossdale PD (1991b) The prevalence of enteric pathogens in diarrheic thoroughbred foals in Britain and Ireland. Equine Veterinary Journal 23: 405-409.

Cavanagh H, Mahony TJ, Vanniasinkam T (2012) Genetic characterization of equine adenovirus type 1. Veterinary Microbiology 155: 33-37. DOI: 10.1016/j.vetmic.2011.08.014

Ciarlet M, Isa P, Conner ME, Liprandi F (2001) Antigenic and molecular analyses reveal that the equine rotavirus strain $\mathrm{H}-1$ is closely related to porcine, but not equine, rotaviruses: interspecies transmission from pigs to horses? Virus Genes 22: $5-20$.

Ciarlet M, Reggeti F, Pina CI, Liprandi F (1994) Equine rotaviruses with G14 serotype specificity circulate among Venezuelan horses. Journal of Clinical Microbiology 32: 2609-2612.

Collins PJ, Cullinane A, Martella V, O'Shea H (2008) Molecular characterization of equine rotavirus in Ireland. Journal Clinical Microbiology 46: 3346-3354. DOI: 10.1128/JCM.00995-08

Cowley D, Donato CM, Roczo-Farkas S, Kirkwood CD (2016) Emergence of a novel equine-like G3P [8] inter-genogroup reassertant rotavirus strain associated with gastroenteritis in Australian children. Journal of General Virology 97: 403-410. DOI: $10.1099 /$ jgv.0.000352.

Cullinane A, Newton JR (2013) Equine influenza - a global perspective. Veterinary Microbiology 167: 205-214. DOI: 10.1016/j.vetmic.2013.03.029

Davis E, Rush BR, Cox J, DeBey B, Kapil S (2000) Neonatal enterocolitis associated with coronavirus infection in a foal: A case report. Journal of Veterinary Diagnostic Investigation 12: 153-156.

Davison AJ, Benko M, Harrach B (2003) Genetic content and evolution of adenoviruses. Journal of General Virology 84: 2895-2908. DOI: 10.1099/vir.0.19497-0
Decaro N, Buonavoglia C (2008) An update on canine coronaviruses: Viral evolution and pathobiology. Veterinary Microbiology 132: 221-234.DOI: 10.1016/j.vetmic. 2008.06 .007

Decaro N, Cirone F, Mari V, Nava D, Tinelli A, Elia G, Di Sarno A, Martella V, Colaianni ML, Aprea G, Tempesta M, Buonavoglia C (2010) Characterisation of bubaline coronavirus strains associated with gastroenteritis in water buffalo (Bubalusbubalis) calves. Veterinary Microbiology 145: 245-251. DOI: 10.1016/j.vetmic

Dhama K, Malik YS, Malik SVS, Singh RK (2015a) Ebola from emergence to epidemic: the virus and the disease, global preparedness and perspectives. The Journal of Infection in Developing Countries 9: 441-455. DOI: 10.3855/jidc.6197

Dhama K, Pawaiya RVS, Chakraborty S, Tiwari R, Saminathan M, Verma AK (2014) Coronavirus Infection in Equines: A Review. Asian Journal of Animal and Veterinary Advances 9: 164-176.DOI: 10.3923/ajava.2014.164.176

Dhama K, Saminathan M, Karthik K, Tiwari R, Shabbir MZ, Kumar N, Malik YS, Singh RK (2015b) Avian rotavirus enteritis-an updated review. Veterinary Quarterly 35: 142-158. DOI: $10.1080 / 01652176.2015$

Dóró R, Marton S, Bartókné AH, Lengyel G, Agócs Z, Jakab F, Bányai K (2016) Equine-like G3 rotavirus in Hungary, 2015-Is it a novel intergenogroup reassortant pandemic strain?. Acta Microbiologicaet Immunologica Hungarica 63: 243-255.

Durham PJK, Stevenson BJ, Farquharson BC (1979) Rotavirus and coronavirus associated diarrhoea in domestic animals. New Zealand Veterinary Journal 27: 30-32.DOI: 10.1080/00480169.1979.34595

Eichhorn W, Huan-Chun C (1987) Serological survey of the prevalence of rotavirus antibodies in horses. TierarztlicheUmschau 42: 22-23.

Elschner M, Schrader C, Hotzel H, Prudlo J, Sachse K, Eichhorn W, Herbst W, Otto P (2005) Isolation and molecular characterisation of equine rotaviruses from Germany. Veterinary Microbiology 105: 123-129.DOI: 10.1016/j.vetmic.2004.10.010

Erles K, Shiu KB, Brownlie J (2007) Isolation and sequence analysis of canine respiratory coronavirus. Virus Research 124: 78-87. DOI: $10.1016 /$ j.virusres.2006.10.004

Estes MK, Kapikian AZ (2007) Rotaviruses and their replication. In: Knipe DM, Howley PM, Griffin DE, Lamb RA, Martin MA, Roizman B, Straus SE (Eds.) Fields Virology. Lippincott, Williams \& Wilkins, Philadelphia, USA. 
Fielding CL, Higgins JK, Higgins JC, McIntosh S, Scott E, Giannitti F, Mete A, Pusterla N (2015) Disease associated with equine coronavirus infection and high case fatality rate. Journal of Veterinary Internal Medicine 29: 307-310. DOI: $10.1111 /$ jvim. 12480

Flewett TH, Bryden AS, Davies H (1975) Letter: Virus diarrhoea in foals and other animals. Veterinary Record 96: 21.

Franco Ayala MS, Oliver Espinosa OJ (2015) Diseases of Newborn Foals and their Epidemiology: A Review. Revista de Medicina Veterinaria 29: 91-105.

Frederick J, Giguere S, Sanchez LC (2009) Infectious agents detected in the feces of diarrheic foals: a retrospective study of 233 cases (2003- 2008). Journal of Veterinary Internal Medicine 23: $1254-1260$. DOI: $10.1111 /$ j.19391676.2009.0383.x.

Fukai K, Saito T, Fukuda O, Hagiwara A, Inoue K, Sato M (2006) Molecular characterisation of equine group A rotavirus, Nasuno, isolated in Tochigi Prefecture, Japan. The Veterinary Journal 172: 369-373. DOI: 10.1016/j.tvj1.2005.05.004

Ganesh B, Bányai K, Kanungo S, Sur D, Malik YS, Kobayashi N (2012) Detection and molecular characterization of porcine picobirnavirus in feces of domestic pigs from Kolkata, India. Indian Journal of Virology 23: 387-391. DOI: 10.1007/s13337012-0106-Z

Ganesh B, Banyai K, Masachessi G, Mladenova Z, Nagashima S, Ghosh S, Nataraju SM, Pativada M, Kumar R, Kobayashi N (2011) Geno-group I picobirnavirus in diarrhoeic foals: can the horse serve as a natural reservoir for human infection? Veterinary Research 42: 52. DOI: 10.1186/1297-9716-42-52

Garaicoechea L, Mino S, Ciarlet M, Fernandez F, Barrandeguy M, Parreno V (2011) Molecular characterization of equine rotaviruses circulating in Argentinean foals during a 17-year surveillance period (1992-2008). Veterinary Microbiology 148: 150-160. DOI: 10.1016/j.vetmic.2010.08.032.

Ghosh S, Kobayashi N (2014) Exotic rotaviruses in animals and rotaviruses in exotic animals. Virus Disease 25: 158-172

Ghosh S, Shintani T, Kobayashi N (2012) Evidence for the porcine origin of equine rotavirus strain $\mathrm{H}-1$. Veterinary Microbiology 158: 410-414.DOI: 10.1016/j.vetmic.2012.02.037

Ghosh S, Taniguchi K, Aida S, Ganesh B, Kobayashi N (2013) Whole genomic analyses of equine group A rotaviruses from Japan: evidence for bovine-to-equine interspecies transmission and reassortment events. Veterinary Microbiology 166: 474485. DOI: 10.1016/j.vetmic.2013.07.016.

Giles C, Cavanagh HM, Noble G, Vanniasinkam T (2010) Prevalence of equine adenovirus antibodies in horses in New
South Wales, Australia. Veterinary Microbiology 143: 401404. DOI: 10.1016/j.vetmic.2009.11.042.

Giles C, Vanniasinkam T, Barton M, Mahony TJ (2015) Characterisation of the Equine adenovirus 2 genome. Veterinary Microbiology 179: 184-189. DOI: 10.1016/j.vetmic.2015.07.024.

Gillman L, Sánchez AM, Arbiza J (2013) Picobirnavirus in captive animals from Uruguay: identification of new hosts. Intervirology 56: 46-49. DOI: 10.1159/000338275

Gouvea V, Santos N, do C Timenetsky M (1994) Identification of bovine and porcine rotavirus $\mathrm{G}$ types by PCR. Journal of Clinical Microbiology 32: 1338-1340.

Gulati BR, Deepa R, Singh BK, Rao CD (2007) Diversity in Indian equine rotaviruses: identification of genotype G10, P6[1] and G1 strains and a new VP7 genotype (G16) strain in specimens from diarrheic foals in India. Journal of Clinical Microbiology 45: 972-978. DOI: 10.1128/JCM.01696-06

Gulati BR, Yadav RR, Singh BK (2009) Epidemiological studies on equine rotavirus infection in foals of organized farms in India. Indian Journal of Animal Sciences 79: 3-5.

Guy JS, Breslin JJ, Breuhaus B, Vivrette S, Smith LG (2000) Characterization of a coronavirus isolated from a diarrheic foal. Journal of Clinical Microbiology 38: 4523-4526.

Hardy ME, Woode GN, Xu ZC, Williams JD, Conner ME, Dwyer RM, Powell DG (1991) Analysis of serotypes and electropherotypes of equine rotaviruses isolated in the United States. Journal of Clinical Microbiology 29: 889-893.

Harrach B, Benkö M, Both GW, Brown M, Davison A, Echavarria M, Hess M, Jones M, Kajon A, Lehmkuhl H, Mautner V, Mittal S, Wadell G (2011) Family Adenoviridae. In: King A, Adams M, Carstens E, Lefkowitz E (Eds.) Virus Taxonomy: Classification and Nomenclature of Viruses. Ninth Report of the International Committee on Taxonomy of Viruses, Elsevier, San Diego, USA.

Holmes KV (2001) Coronaviruses, In: Knipe DM, Howley PM, Griffin DE, Lamb RA, Martin MA, Roizman B, Straus SE (Eds.) Fields Virology, Lippincott Williams and Wilkins, Philadelphia, USA.

Horner GW, Hunter R (1982) Isolation of two serotypes of equine adenovirus from horses in New Zealand. New Zealand Veterinary Journal 30: 62-64.

Huang JC, Wright SL, Shipley WD (1983) Isolation of coronavirus-like agent from horses suffering from acute equine diarrhoea syndrome. Veterinary Record 113: 262-263.

Imagawa H, Fukunaga Y, Kamada M (1990) Detection of neutralizing antibody against calf diarrheal coronavirus in 
horse serum. Bulletin of Equine Research Institute, Japan 1990: 25-30.

Imagawa H, Ishida SI, Uesugi S, Masanobu K, Fukunaga Y, Nakagomi O (1994) Genetic analysis of equine rotavirus by RNA-RNA hybridization. Journal of Clinical Microbiology 32: 2009-2012.

Imagawa H, Kato T, Tsunemitsu H, Tanaka H, Sato S, Higuchi $\mathrm{T}$ (2005) Field study of inactivated equine rotavirus vaccine. Journal of Equine Science 16: 35-44. DOI: 10.1294/jes.16.35

Imagawa H, Sekiguchi K, Anzai T, Fukunaga Y, Kanemaru T, Ohishi H, Higuchi T, Kamada M (1991) Epidemiology of equine rotavirus infection among foals in the breeding region. Journal of Veterinary Medical Science 53: 1079-1080.

Imagawa H, Sugiura T, Ryuichi WA, Hirasawa K, Akiyama Y(1981) Isolation of foal rotavirus in MA-104 cells. Bulletin of Equine Research Institute 18: 119-128.

Imagawa H, Tanaka T, Sekiguchi K, Fukunaga Y, Anzai T, Minamoto N, Kamada M (1993) Electropherotypes, serotypes, and subgroups of equine rotaviruses isolated in Japan. Archives of Virology 131: 169-176.

Isa P, Snodgrass DR (1994) Serological and genomic characterization of equine rotavirus VP4 proteins identifies 3 different P-serotypes. Virology 201: 364-372.

Isa P, Wood AR, Netherwood T, Ciarlet M, Imagawa H, Snodgrass DR (1996) Survey of equine rotaviruses shows conservation of one $\mathrm{P}$ genotype in background of two $\mathrm{G}$ genotypes. Archives of Virology 141: 1601-1612.

Jamieson FB, Wang EE, Bain C, Good J, Duckmanton L, Petric M (1998) Human torovirus: a new nosocomial gastrointestinal pathogen. Journal of Infectious Diseases 178: 1263-1269.

Johnson AL (2011) Update on infectious diseases affecting the equine nervous system. Veterinary Clinics of North America: Equine Practice 27: 573-587. DOI: 10.1016/j.cveq.2011.08.008

Kanitz CL (1977) Identification of an equine rotavirus as a cause of neonatal foal diarrhea. In Proceedings-Annual Convention of the American Association of Equine Practitioners (USA).

Khurana SK, Dhama K, Prasad M, Karthik K, Tiwari R (2015) Zoonotic pathogens transmitted from equines: diagnosis and control. Advances in Animal and Veterinary Science 3: 32-53. DOI: 10.14737/journal.aavs/2015/3.2s.32.53

Kojima K, Taniguchi K, Kobayashi N (1996) Species-specific and interspecies relatedness of NSP1 sequences in human, porcine, bovine, feline, and equine rotavirus strains. Archives of Virology 141: 1-12.

Kooijman LJ, MapesSM, PusterlaN (2016) Development of an equine coronavirus-specific enzyme-linked immunosorbent assay to determine serological responses in naturally infected horses. Journal of Veterinary Diagnostic Investigation 28: 414418. DOI: $10.1177 / 1040638716649643$

Ksiazek TG, Erdman D, Goldsmith CS, Zaki SR, Peret T, Emery S, Tong S, Urbani C, Comer JA, Lim W, Rollin PE (2003) A novel coronavirus associated with severe acute respiratory syndrome. New England Journal of Medicine 348: 1953-1966. DOI: 10.1056/NEJMoa030781

Lai MM, Holmes KV (2001) Coronaviridae: The Viruses and their Replication. In: Knipe DM, Howley PM (Ed) Fields Virology, Lippincott Williams and Wilkins, USA.

Li L, Giannitti F, Low J, Keyes C, Ullmann LS, Deng X, Aleman M, Pesavento PA, Pusterla N, Delwart E (2015) Exploring the virome of diseased horses. Journal of General Virology 96: 2721-2733. DOI: 10.1099/vir.0.000199

Malasao R, Saito M, Suzuki A, Imagawa T, Nukiwa-Soma N, Tohma K, Liu X, Okamoto M, Chaimongkol N, Dapat C, Kawamura K (2015) Human G3P [4] rotavirus obtained in Japan, 2013, possibly emerged through a human-equine rotavirus reassortment event. Virus Genes 50: 129-133. DOI: $10.1007 / \mathrm{s} 11262-014-1135-\mathrm{z}$

Malik YS, Chandrashekar KM, Sharma K, Haq AA, Vaid N, Chakravarti S, Batra M, Singh R, Pandey AB (2011) Picobirnavirus detection in bovine and buffalo calves from foothills of Himalaya and Central India. Tropical Animal Health and Production 43: 1475-1478. DOI: 10.1007/s11250011-9834-0

Malik YS, Kumar N, Sharma K, Dhama K, Shabbir MZ, Ganesh B, Kobayashi N, Banyai K (2014) Epidemiology, phylogeny, and evolution of emerging enteric Picobirnaviruses of animal origin and their relationship to human strains. BioMed Research International 2014:780752. DOI: 10.1155/2014/780752.

Malik YS, Kumar N, Sharma K, Sharma AK, Sircar S, Jeena L M, Balasubramanian G (2013) Molecular characterization of a genetically diverse bubaline picobirnavirus strain, India. The Thai Journal of Veterinary Medicine 43: 609.

Matthijnssens J, Miño S, Papp H, Potgieter C, Novo L, Heylen E, Zeller M, Garaicoechea L, Badaracco A, Lengyel G, Kisfali P (2012b) Complete molecular genome analyses of equine rotavirus A strains from different continents reveal several novel genotypes and a largely conserved genotype constellation. Journal of General Virology 93: 866-875.DOI: 10.1099/vir.0.039255-0 
Matthijnssens J, Otto PH, Ciarlet M, Desselberger U, Van Ranst M, Johne R (2012a) VP6-sequence-based cut-off values as a criterion for rotavirus species demarcation. Archives of Virology 157: 1177-1182. DOI: 10.1007/s00705-012-1273-3.

Matthijnssens J, Potgieter CA, Ciarlet M, Parreno V, Martella V, Banyai K, Garaicoechea L, Palombo EA, Novo L, Zeller M, Arista S (2009) Are human P [14] rotavirus strains the result of interspecies transmissions from sheep or other ungulates that belong to the mammalian order Artiodactyla?. Journal of Virology 83: 2917-2929. DOI: 10.1128/JVI.02246-08

McIntosh K (1996) Diagnostic virology. In Fields BN, Knipe DM, Howley PM, Chanock RM, Melnick JK, Monath TP (Ed). Fields Virology, Lippincott-Raven Publishers, Philadelphia, USA.

McIntosh K (2002) Clinical Virology: Coronaviruses. ASM Press, Washington, DC, USA.

Mihalov-Kovács E, Gellért Á, Marton S, Farkas SL, Fehér E, Oldal M, Jakab F, Martella V, Banyai K (2015) Candidate new rotavirus species in sheltered dogs, Hungary. Emerging Infectious Diseases 21: 660-663. DOI: 10.3201/eid2104.141370

Minakshi P, Malik YS, Pandey R (2005) G and P genotyping of bovine group A rotaviruses in faecal samples of diarrhoeic calves by DIG-labelled probes. Indian Journal of Biotechnology 4: 93-99.

Mino S, Matthijnssens J, Badaracco A, Garaicoechea L, Zeller M, Heylen E, Van Ranst M, Barrandeguy M, Parreno V (2013) Equine G3P [3] rotavirus strain E3198 related to simian RRV and feline/canine-like rotaviruses based on complete genome analyses. Veterinary Microbiology 161: 239-246. DOI: 10.1016/j.vetmic.2012.07.033

Miszczak F, Kin N, Tesson V, Vabret A (2016) Real-Time RTPCR Detection of Equine Coronavirus. Animal Coronaviruses 93-100. DOI: 10.1007/978-1-4939-3414-0_8

Miszczak F, Tesson V, Kin N, Dina J, Balasuriya UB, Pronost S, Vabret A (2014) First detection of equine coronavirus (ECoV) in Europe. Veterinary Microbiology 171: 206-209. DOI: 10.1016/j.vetmic.2014.03.031

Monini M, Biasin A, Valentini S, Cattoli G, Ruggeri FM (2011) Recurrent rotavirus diarrhoea outbreaks in a stud farm, in Italy. Veterinary Microbiology 149:248-253. DOI: 10.1016/j.vetmic.2010.11.007

Mukarim A, Dechassa T, Mahendra P (2015) Equine Bacterial and Viral Zoonosis: A Systematic Review. Austin Journal of Tropical Medicine and Hygiene 1: 1001-1006.

Nemoto M, Hata H, Higuchi T, Imagawa H, Yamanaka T, Niwa H, Bannai H, Tsujimura K, Kondo T, Matsumura T (2010a) Evaluation of rapid antigen detection kits for diagnosis of equine rotavirus infection. Journal of Veterinary Medical Science 72: 1247-1250. DOI: 10.1292/jvms.10-0064

Nemoto M, Imagawa H, Tsujimura K, Yamanaka T, Kondo T, Matsumura T (2010b) Detection of equine rotavirus by reverse transcription loop-mediated isothermal amplification (RTLAMP). Journal of Veterinary Medical Science 72: 823-826.

Nemoto M, Morita Y, Niwa H, Bannai H, Tsujimura K, Yamanaka T, Kondo T (2015a) Rapid detection of equine coronavirus by reverse transcription loop-mediated isothermal amplification. Journal of Virological Methods 215: 13-16.

Nemoto M, Nagai M, Tsunemitsu H, Omatsu T, Furuya T, Shirai J, Kondo T, Fujii Y, Todaka R, Katayama K, Mizutani T (2015c) Whole-genome sequence analysis of G3 and G14 equine group A rotaviruses isolated in the late 1990s and 20092010. Archives of Virology 160: 1171-1179.

Nemoto M, Oue Y, Morita Y, Kanno T, Kinoshita Y, Niwa H, Ueno T, Katayama Y, Bannai H, Tsujimura K, Yamanaka T (2014) Experimental inoculation of equine coronavirus into Japanese draft horses. Archives of Virology 159: 3329-3334.

Nemoto M, Oue Y, Murakami S, Kanno T, Bannai H, Tsujimura K, Yamanaka T, Kondo T (2015b) Complete genome analysis of equine coronavirus isolated in Japan. Archives of Virology 160: 2903-2906.

Nemoto M, Tsunemitsu H, Imagawa $H$, Hata H, Higuchi T, Sato S, Orita Y, Sugita S, Bannai H, Tsujimura K, Yamanaka $\mathrm{T}$ (2011) Molecular characterization and analysis of equine rotavirus circulating in Japan from 2003 to 2008. Veterinary Microbiology 152: 67-73.

Nemoto M, Tsunemitsu H, Murase H, Nambo Y, Sato S, Orita $\mathrm{Y}$, Imagawa $\mathrm{H}$, Bannai $\mathrm{H}$, Tsujimura $\mathrm{K}$, Yamanaka $\mathrm{T}$, Matsumura T (2012) Antibody response in vaccinated pregnant mares to recent G3BP [12] and G14P [12] equine rotaviruses. ActaVeterinariaScandinavica 54: 63.

Ng TF, Vega E, Kondov NO, Markey C, Deng X, Gregoricus N, Vinjé J, Delwart E (2014) Divergent picobirnaviruses in human feces. Genome Announcements 2: 00415-14.

Ntafis V, Fragkiadaki E, Xylouri E, Omirou A, Lavazza A, Martella V (2010) Rotavirus-associated diarrhoea in foals in Greece. Veterinary Microbiology 144: 461-465.

Onmaz AC, Beutel RG, Schneeberg K, Pavaloiu AN, Komarek A, Van den Hoven R (2013) Vectors and vector-borne diseases of horses. Veterinary Research Communications 37: 65-81.

Oue Y, Ishihara R, Edamatsu H, Morita Y, Yoshida M, Yoshima M (2011) Isolation of an equine coronavirus from adult horses with pyrogenic and enteric disease and its 
antigenic and genomic characterization in comparison with the NC99 strain. Veterinary Microbiology 150: 41-48.

Oue Y, Morita Y, Kondo T, Nemoto M (2013) Epidemic of equine coronavirus at Obihiro Racecourse, Hokkaido, Japan in 2012. Journal of Veterinary Medical Science 75: 1261-1265.

Papp H, Matthijnssens J, Martella V, Ciarlet M, Banyai K (2013) Global distribution of group A rotavirus strains in horses: a systematic review. Vaccine 31: 5627-5633.

Pearson NJ, Fulton RW, Issel CJ, Springer WT (1982) Prevalence of rotavirus antibody in chickens and horses in Louisiana, USA. Veterinary Record 110: 58-59.

Pusterla N, Holzenkaempfer N, Mapes S, Kass P (2015b) Prevalence of equine coronavirus in nasal secretions from horses with fever and upper respiratory tract infection. Veterinary Record 177: 289-291.

Pusterla N, Mapes S, Wademan C, White A, Ball R, Sapp K (2013) Emerging outbreaks associated with equine coronavirus in adult horses. Veterinary Microbiology 162: 228-231.

Pusterla N, Vin R, Leutenegger C, Mittel LD, Divers TJ (2015a) Equine coronavirus: An emerging enteric virus of adult horses. Equine Veterinary Education 28: 216-223.

Puyalto-Moussu C, Taouji S (2002) Epidemiology and prophylaxis of neonatal diarrhoea in the foal-preliminary results of a study carried out in Normandy. Journée de la Recherche Equine 25-33.

Reed S, Traub J, Evermann J, Bayly W, Penney R (1983) Foal enteritis [Viruses, bacteria]. Equine Practice 5: 19-30.

Resta S, Luby JP, Rosenfeld CR, Siegel JD (1985) Isolation and propagation of a human enteric coronavirus. Science 229: 978-981.

Reubel GH, Studdert MJ (1997) Sequence analysis of equine adenovirus 2 hexon and $23 \mathrm{~K}$ proteinase genes indicates a phylogenetic origin distinct from equine adenovirus 1. Virus Research 50: 41-56.

Ribeiro SR, Bezerra DAM, Kaiano JHL, Oliveira DS, Silvestre RVD, Gabbay YB, Ganesh B, Mascarenhas JDP (2014) Genogroup I avian picobirnavirus detected in Brazilian broiler chickens: a molecular epidemiology study. Journal of General Virology 95: 117-122.

Saif LJ, Brock KV, Redman DR, Kohler EM (1991) Winter dysentery in dairy herds: electron microscopic and serological evidence for an association with coronavirus infection. Veterinary Record 128: 447-449.
Schroeder BA, Kalmakoff J, Holdaway D, Todd BA (1983) The isolation of rotavirus from calves, foals, dogs and cats in New Zealand. New Zealand Veterinary Journal 31: 114-116.

Singh RK, Dhama K, Malik YS, Ramakrishnan MA, Karthik K, Tiwari R, Saurabh S, Sachan S, Joshi SK (2016) Zika Virus-Emergence, evolution, pathology, diagnosis and control: current global scenario and future perspectives-A comprehensive review. Veterinary Quarterly 36: 1-43. doi.org/10.1080/01652176.2016.1188333

Slater J (2013) Fromglanders to Hendra virus: 125 years of equine infectious diseases. Veterinary Record 173: 186-189.

Slovis NM, Elam J, Estrada M, Leutenegger M (2014) Infectious agents associated with diarrhea in neonatal foals in central Kentucky: a comprehensive molecular study. Equine Veterinary Journal 46: 311-316.

Slovis NM, Elam J, Estrada M, Thao MF, Leutenegger CM (2010) Comprehensive analysis of infectious agents associated with diarrhea in foals in Central Kentucky. In Proceedings of American Association of Equine Practitioners 56: 262-266.

Smith EC, Blanc H, Vignuzzi M, Denison MR (2013) Coronaviruses lacking exoribonuclease activity are susceptible to lethal mutagenesis: evidence for proofreading and potential therapeutics. PLoS Pathogens 9: 1003565.

Smith EC, Denison MR (2012) Implications of altered replication fidelity on the evolution and pathogenesis of coronaviruses. Current Opinion in Virology 2: 519-524.

Smits SL, Poon LLM, Van leeuwen M, Lau PN, Perera HKK, Malik Peiris JS, Simon JH, Osterhaus DME (2011) Genogroup I and II picobirnaviruses in respiratory tracts of pigs. Emerging Infectious Diseases 17: 2328-2330.

Smits SL, Schapendonk CM, van Beek J, Vennema H, Schürch AC, Schipper D, Bodewes R, Haagmans BL, Osterhaus AD, Koopmans MP (2014) New viruses in idiopathic human diarrhea cases, the Netherlands. Emerging Infectious Diseases 20: $1218-1222$.

Strauss JH, Strauss EG (2002) Plus-Strand RNA and DoubleStrand RNA Viruses, Coronaviridae. In: Strauss JH, Strauss EG (Eds.) Viruses and Human Disease, Academic Press, San Diego, USA.

Strickland KL, Lenihan P, Oconnor MG, Condon JC (1982) Diarrhea in foals associated with rotavirus. Veterinary Record 111: 421-421.

Studdert MJ (1978) Antigenic homogeneity of equine adenoviruses. Australian Veterinary Journal 54: 263-264. 
Studdert MJ (1996) Coronavirus Infections. In: Horzinek MC, MJ Studdert (Eds) Virus Infections of Vertebrates: Virus Infections of Equines, Elsevier, London, UK.

Studdert MJ, Blackney MH (1982) Isolation of an adenovirus antigenically distinct from equine adenovirus type 1 from diarrheic foal feces. American Journal of Veterinary Research 43: 543-544.

Studdert MJ, Mason RW, Patten BE (1978) Rotavirus diarrhoea of foals. Australian Veterinary Journal 54: 363-364.

Takagi M, Taniguchi K, Urasawa T, Urasawa S, Shirahata T, Goto H (1994) Characterization of a G14 equine rotavirus (strain CH3) isolated in Japan. Archives of Virology 139: 209215.

Takiuchi E, Macedo R, Kunz AF, Gallego JC, de Mello JL, Otonel RA, Alfieri AA (2016) Electrophoretic RNA genomic profiles of Brazilian Picobirnavirus (PBV) strains and molecular characterization of a PBV isolated from diarrheic calf. Virus Research 211: 58-63.

Taniguchi K, Urasawa T, Urasawa S (1994) Species specificity and interspecies relatedness in VP4 genotypes demonstrated by VP4 sequence analysis of equine, feline, and canine rotavirus strains. Virology 200: 390-400.

Todd JD (1969) Comments on rhinoviruses and parainfluenza viruses of horses. Journal of the American Veterinary Medical Association 155: 387.

Tsunemitsu H, Imagawa H, Togo M, Shouji T, Kawashima K, Horino R, Imai K, Nishimori T, Takagi M, Higuchi T (2001) Predominance of G3B and G14 equine group A rotaviruses of a single VP4 serotype in Japan. Archives of Virology 146: 1949-1962.

Tzipori S, Walker M (1978) Isolation of rotavirus from foals with diarrhoea. Australian Journal of Experimental Biology and Medical Science 56: 453-457.

Van der Heide R, Koopmans MP, Shekary N, Houwers DJ, Van Duynhoven YT, Van der Poel WH (2005) Molecular characterizations of human and animal group A rotaviruses in the Netherlands. Journal of Clinical Microbiology 43: 669-675.
Van der Hoek L, Pyrc K, Jebbink MF, Vermeulen-Oost W, Berkhout RJ, Wolthers KC, Wertheim-van Dillen PM, Kaandorp J, Spaargaren J, Berkhout B (2004) Identification of a new human coronavirus. Nature Medicine 10: 368-373.

Verma H, Mor SK, Erber J, Goyal SM (2015) Prevalence and complete genome characterization of turkey picobirnaviruses. Infection, Genetics and Evolution 30: 134-139.

Weiss SR, Navas-Martin S (2005) Coronavirus pathogenesis and the emerging pathogen severe acute respiratory syndrome coronavirus. Microbiology and Molecular Biology Reviews 69: 635-664.

White DE, Fenner FJ (1994) Coronaviridae: Medical Virology, White DE, Fenner FJ (Ed) Academic Press, San Diego, USA.

Wong FC, Spearman JG, Smolenski MA, Loewen PC (1985) Equine parvovirus: initial isolation and partial characterization. Canadian Journal of Comparative Medicine 49: 50.

Woo PC, Lau SK, Lam CS, Lau CC, Tsang AK, Lau JH, Bai R, Teng JL, Tsang CC, Wang M, Zheng BJ, Chan KH, Yuen KY (2012) Discovery of seven novel mammalian and avian coronaviruses in the genus Deltacoronavirus supports bat coronaviruses as the gene source of Alphacoronavirus and Betacoronavirus and avian coronaviruses as the gene source of Gammacoronavirus and Deltacoronavirus. Journal of Virology 86: 3995-4008.

Woo PC, Lau SK, Teng JL, Tsang AK, Joseph M, Wong EY, Tang Y, Sivakumar S, Bai R, Wernery R, Wernery U, Yuen KY (2014) Metagenomic analysis of viromes of dromedary camel fecal samples reveals large number and high diversity of circoviruses and picobirnaviruses. Virology 471: 117-125.

Wu H, Taniguchi K, Urasawa T, Urasawa S (1993) Genomic relatedness of five equine rotavirus strains with different $G$ serotype and P type specificities. Research in Virology 144: 455-464.

Zhang J, Guy JS, Snijder EJ, Denniston DA, Timoney PJ, Balasuriya UB (2007) Genomic characterization of equine coronavirus. Virology 369: 92-104. 